ISSN 2598-3180 (Online)

JOURNAL OF MIDWIFERY

Re se a r c h a n d P a c ice

\title{
Factors Associated with Antenatal Care Visits at District Of Sungayang Health Center, Tanah Datar Regency In 2017
}

\section{Elsa Gebri Utami, Abdiana, Ayu Nurdiyan}

Bachelor Of Midwifery Program FK-UNAND, Jln Niaga No.56 Padang City, 25127, Indonesia Bachelor Of Midwifery Program FK-UNAND, Jln Niaga No.56 Padang City, 25127, Indonesia Bachelor Of Midwifery Program FK-UNAND, Jln Niaga No.56 Padang City, 25127, Indonesia

\section{SUBMISSION TRACK}

Recieved: Mei 172017

Final Revision: Agustus 18, 2017

Available Online: Nopember 24, 2017

\section{KEYWORD}

Age, Education, Job, Knowledge, Attitude, Support of the Husband

KORESPONDENSI

Phone: 075120120

E-mail:

\begin{abstract}
A B S T R A C T
Antenatal care visits is a behavioral form in the utilization of health services to monitor pregnancy in purpose of improving maternal and fetal health. At public health center of Sungayang, the visit for K1 and K4 did not reach the target for the past three years. In 2016 the coverage for K1 was $70,6 \%$ dan $\mathrm{K} 447,8 \%$ meanwhile the public health center target coverage for K1 is $97 \%$ and K4 95\%. This demonstrate the lack of expectant mothers who make antenatal care visits in accordance with the standards

This study was a quantitative study with cross sectional design conducted at district of Sungayang health center from November 2016 - September 2017. Population and sample of this research is all of the third trimester pregnant women which amounted to 41 women. Data collected by observation and questionnaire. Data analysis was performed using univariate and bivariate.

The results showed $68.3 \%$ of pregnant women do antenatal care visits according to the standard. The result of bivariate analysis shows that there is no correlation between age ( $\mathrm{p}=$ $1,000)$ and job $(p=0,077)$, there is correlation between education $(\mathrm{p}=0,017)$, attitude $(\mathrm{p}=0,014)$, and support of husband ( $\mathrm{p}=0,034)$ with antenatal care visits at district of Sungayang health center in 2017.

There is an association between education, attitude, and support of the husband with antenatal care visits and there is a tendency correlation between knowledge with antenatal care visits.
\end{abstract}

\section{INTRODUCTION}

MMR (Maternal Mortality Rate) is a sensitive indicator in describing the welfare of people of a country and also to the quality and accessibility of health care facilities (Kemenkes RI, 2015). The World Health Organization (WHO) estimates the 830 women died each day from complications of pregnancy and childbirth. Approximately $99 \%$ of all maternal deaths occur in developing countries. The ratio of maternal mortality in developing countries in 2015 is 239 per 100,000 live births compared to 12 per 100,000 live births in developed countries. By the end of 2015, approximately 303,000 women died during and after pregnancy and childbirth. Meanwhile, 2.7 million babies die during the first 28 days of life and 2.6 million babies are born 
dead. Nearly all the deaths occurred because of the things that can be prevented (WHO, 2016).

One of the targets in the Sustainable Development Goals (SDG's 2016-2030) about health at the third points i.e. guarantee healthy life and encourage prosperity for everyone at any age is to reduce maternal mortality globally to less than 70 per 100,000 live births, with no country which has a maternal mortality more than twice the global average (WHO, 2016). Based on the results of the SUPAS 2015 in Indonesia's health profile in 2015, MMR in Indonesia was 305 maternal deaths per 100,000 live births, the number is certainly still far above the target of SDG's.

Ensuring that every mother is able to access high-quality health services is an effort that could accelerate the decline of MMR. In terms of health care of pregnant women can be realized through antenatal services granting at least four times during their pregnancy, with the distribution of the time at least one time in the first trimester, second trimester at one time, two times on the the third trimester. The service time is recommended to ensure the protection for pregnant women and the fetus in the form of early detection of risk factors, prevention, and treatment of complications of early pregnancy (Kemenkes RI, 2015).

The high maternal mortality in Indonesia is related to the low attainment of implementation of Antenatal Care (ANC). Antenatal Care (ANC) is a service provided by health workers to the mother during her pregnancy and carried out in accordance with the standards set out in the Standards of midwifery/SPK (Community Development Directorate of maternal health, Kemkes, RI 2010 Riskesdas Results in 2013). The purpose of ANC is to monitor the progress of pregnancy in improving maternal health and fetal development (Siwi, 2014).

Assessment of the implementation of health service for pregnant women (ANC) can be done by looking at the scope of $\mathrm{K} 1$ and $\mathrm{K} 4$. The scope of $\mathrm{K} 1$ is the number of pregnant women who have obtained the first antenatal services by health workers compared to the number of target pregnant women in a working area in the span of one year. While the coverage of $\mathrm{K} 4$ is the number of pregnant women who have obtained the appropriate antenatal service standard with at least four times on the schedule that is recommended compared to the target number of pregnant women in one work area over a period of one year (Kemenkes RI, 2016).

In the year 2014, the K1 coverage in Indonesia was $94.99 \%$, while for K4 coverage was $86.70 \%$. For coverage of K4, seems still did not reach the target strategic plan (Renstra) Ministry of health health coverage for K4 which is $95 \%$ and there were only two provinces that reach the target that is North Sulawesi and Jakarta (Kemenkes RI, 2015) in 2015, health service coverage for pregnant women K1 was $95.75 \%$ and $\mathrm{K} 4$ coverage was $87.48 \%$. The number meets the target for strategic plan (Renstra) Ministry of health in 2015 for K4 coverage which is $72 \%$. However, this target is lower than the target in 2014 Renstra which is 95\%. However, although the Renstra targets is lowered there still five provinces that have not yet reached the target, Papua, West Papua, East Nusa Tenggara, Maluku, and Central Sulawesi (Kemenkes RI, 2016).

Indonesia's Health Profile in 2015, in West Sumatra K4 coverage was $79.19 \%$, although the $\mathrm{K} 4$ coverage has passed the targets for 2015 Renstra (72\%) but the number has decreased from the previous year, which is $82.70 \%$ (Kemenkes RI, 2016). Then, in the Tanah Datar Regency, in 2013 recorded coverage of K4 65.26\% and debuted two lowest (Kemenkes RI, 2013). In the year 2014, the 94\% coverage $\mathrm{K} 1$ and $\mathrm{K} 4$ coverage $83 \%$ it is still listed under target that is $99 \%$ and $89 \%$ (Dinkes Sumbar, 2015). in 2015 the coverage for (K4) had decline from the previous year, which is $72.40 \%$ (BPS Kab. Tanah Datar 2016).

Sungayang is one of the 14 subdistricts in the Tanah Datar Regency which is the Top 3 lowest K4 coverage. In Sungayang there is a clinic where the target scope of K1 and K4 is $97 \%$ and $95 \%$, but the achievement of year 2015 is $80.77 \%$ and $59.3 \%$ for $\mathrm{K} 1$ and $\mathrm{K} 4$. This has decreased from the previous year (2014), with coverage $94.2 \% \mathrm{~K} 1$ and $\mathrm{K} 4$ coverage was $68.8 \%$. In the year $2016 \mathrm{~K} 1$ and K4 coverage in Sungayang also decline to $70.6 \%$ for K1 coverage and $47.8 \%$ for $\mathrm{K} 4$. This is certainly an issue for the clinics in Sungayang, because in the last three years the coverage for the K1 and K4 always decline, more over if we see from the geographical conditions and access to health services in district Sungayang we can say it's has good access and pregnant mothers should have been better in antenatal care visits in that area. 
Antenatal visit for pregnancy (antenatal care) is a form of behavior in the utilization of health services. According to Lawrence Green in Notoatmodjo (2005) health behaviour of individuals affected by three main factors, predisposing factors, enabling factors, and reinforcing factors. Presdisposisi factors related to the characteristics of individuals that include age, education, employment, culture, knowledge, attitudes, and confidence in the health service. Enabling factors include factors that enable or facilitate conduct or action, include infrastructure or facilities for the occurrence of health behavior, such as health centers, Posyandu, Midwife Clinic etc. The factors that encourage or reinforce the occurrence of behaviors, such as support of the husband, the family, the community leaders (Notoatmodjo, 2005).

The expected goal is to find out factors associated with antenatal care visits at district of Sungayang health center, Tanah Datar Regency in 2017.

\section{METHODS}

This study was a quantitative study with cross sectional design conducted at district of Sungayang health center from November 2016 September 2017. Population and sample of this research is all of the third trimester pregnant women which amounted to 41 women. Data collected by observation and questionnaire. Data analysis was performed using univariate and bivariate.

This study conducted from November 2016September 2017, performed in the region of clinics Sungayang Tanah Datar Regency. The samples were 41 respondents they were three trimester pregnant mothers.

\section{RESULT}

Characteristics Of Respondents

Table 1. The Average Gestational Age of Third Trimester Pregnant Women in Sungayang Health Center, Tanah Datar Regency in 2017

\begin{tabular}{ccccc}
\hline Variables & Mean & SD & $\begin{array}{c}\text { Minimum- } \\
\text { Maximum }\end{array}$ & $\begin{array}{c}\text { 95\% } \\
\text { CI }\end{array}$ \\
\hline $\begin{array}{c}\text { Gestasional } \\
\text { age }\end{array}$ & 34,80 & $\pm 2,32$ & $32-39$ & $\begin{array}{c}34,07- \\
35,54\end{array}$ \\
\hline
\end{tabular}

Based on table 1 above, the analysis results obtained average maternal gestational age was 34.80 weeks (95\% CI: 34.0 - 35.54), with a standard deviation of \pm 2.32 weeks. The youngest is 32 weeks gestational age and the oldest pregnancy is 39 weeks.

Table 2. Distribution of Frequency of Antenatal Care Visits at District of Sungayang Health Center, Tanah Datar Regency in 2017

\begin{tabular}{ccc}
\hline $\begin{array}{c}\text { Antenatal Care } \\
\text { Visits }\end{array}$ & $\begin{array}{c}\text { Frequency } \\
(\mathbf{n = 4 1})\end{array}$ & $\begin{array}{c}\text { Percentage } \\
(\mathbf{\%})\end{array}$ \\
\hline $\begin{array}{c}\text { Not according } \\
\text { standard }\end{array}$ & 13 & 31,7 \\
$\begin{array}{c}\text { According to the } \\
\text { standard } \\
\text { Total }\end{array}$ & 28 & 68,3 \\
\hline
\end{tabular}

Based on table 2 above it can be seen that out of 41 respondents, the majority of respondents do antenatal care visits according to the standard $68.3 \%$.

Table 3. The Association of Age of Pregnant Women with Antenatal Care Visits at District of Sungayang Health Center, Tanah Datar Regency in 2017

\begin{tabular}{|c|c|c|c|c|c|c|c|c|}
\hline \multirow{3}{*}{ Age } & \multicolumn{4}{|c|}{ Antenatal Care Visits } & & & \multirow{3}{*}{$\begin{array}{c}\text { POR } \\
(95 \% \\
\text { CI })\end{array}$} & \multirow{3}{*}{$\begin{array}{c}p- \\
\text { valu } \\
e\end{array}$} \\
\hline & \multicolumn{2}{|c|}{$\begin{array}{c}\text { Not } \\
\text { according } \\
\text { standard }\end{array}$} & \multicolumn{2}{|c|}{$\begin{array}{l}\text { Accordin } \\
\text { g to the } \\
\text { standard }\end{array}$} & \multicolumn{2}{|c|}{ Total } & & \\
\hline & f & $\%$ & $\mathbf{F}$ & $\%$ & $\mathbf{F}$ & $\%$ & & \\
\hline Risk & 1 & 33,3 & 2 & 66,7 & 3 & 100 & & \\
\hline $\begin{array}{c}\text { Not at } \\
\text { risk }\end{array}$ & 12 & 31,6 & 26 & 68,4 & 38 & 100 & $\begin{array}{c}1,083 \\
(0,089- \\
13,145)\end{array}$ & $\begin{array}{c}1,00 \\
0\end{array}$ \\
\hline Total & 13 & 31,7 & 28 & 68,3 & 41 & 100 & & \\
\hline
\end{tabular}

Based on table 3 above, it shows that pregnant women with antenatal care visits according to standard is more for unrisk woman $(68.4 \%)$, compared to a risk age woman $(66.7 \%)$. Based on statistical tests $\mathrm{p}$ value $=1.000(\mathrm{p}>$ 0.05 ), it means there is no correlation between age of pregnant women with antenatal care visits at District Of Sungayang Health Center, Tanah Datar Regency in 2017. 
Table 4. The Association Education of Pregnant Women with Antenatal Care Visits at District of Sungayang Health Center, Tanah Datar Regency in 2017

\begin{tabular}{|c|c|c|c|c|c|c|c|c|}
\hline \multirow{3}{*}{$\begin{array}{c}\text { Educati } \\
\text { on }\end{array}$} & \multicolumn{4}{|c|}{$\begin{array}{c}\text { Antenatal Care } \\
\text { Visits }\end{array}$} & & & \multirow{3}{*}{$\begin{array}{c}\text { POR } \\
(95 \% \\
\text { CI })\end{array}$} & \multirow{3}{*}{$\begin{array}{c}p- \\
\text { value }\end{array}$} \\
\hline & \multicolumn{2}{|c|}{$\begin{array}{c}\text { Not } \\
\text { accordin } \\
\text { g } \\
\text { standard }\end{array}$} & \multicolumn{2}{|c|}{$\begin{array}{l}\text { Accordin } \\
\text { g to the } \\
\text { standard }\end{array}$} & \multicolumn{2}{|c|}{ Total } & & \\
\hline & f & $\%$ & $\mathbf{f}$ & $\%$ & $\mathbf{f}$ & $\%$ & & \\
\hline Low & 8 & 57,1 & 6 & 42,9 & 13 & 100 & 5,867 & \\
\hline High & 5 & 18,5 & 22 & 81,5 & 28 & 100 & $(1,395-$ & 0,017 \\
\hline Total & 13 & 31,7 & 28 & 68,3 & 41 & 100 & $24,673)$ & \\
\hline
\end{tabular}

Based on the table 4 above, its shows that pregnant women with antenatal care visits according to standard is more on mothers with higher education $(81.5 \%)$ compared to mother with low education (42.9)\%. Based on statistical tests $\mathrm{p}$ value $=0.017(\mathrm{p}<0.05)$, it means there is a significant association between the education of pregnant women with antenatal care visits at District of Sungayang Health Center, Tanah Datar Regency in 2017.

Table 5. The Association of Job of Pregnant Women with Antenatal Care Visits at District of Sungayang Health Center, Tanah Datar Regency in 2017

\begin{tabular}{|c|c|c|c|c|c|c|c|c|c|c|c|c|c|c|c|c|}
\hline \multirow{4}{*}{ Job } & \multicolumn{4}{|c|}{ Antenatal Care Visits } & & & & & & & & & & & & \\
\hline & \multirow{2}{*}{\multicolumn{2}{|c|}{$\begin{array}{c}\text { Not } \\
\text { according } \\
\text { standard }\end{array}$}} & \multirow{2}{*}{\multicolumn{2}{|c|}{$\begin{array}{l}\text { According } \\
\text { to the } \\
\text { standard }\end{array}$}} & \multirow{2}{*}{\multicolumn{2}{|c|}{ Total }} & \multirow{3}{*}{$\begin{array}{c}\text { POR } \\
(95 \% \\
\text { CI })\end{array}$} & \multirow{3}{*}{$\begin{array}{c}p- \\
\text { value } \\
\text { Attitude }\end{array}$} & \multicolumn{4}{|c|}{ Antenatal Care Visits } & \multirow{3}{*}{\multicolumn{2}{|c|}{ Total }} & \multirow{4}{*}{$\begin{array}{c}\text { POR } \\
(95 \% \\
\text { CI })\end{array}$} & \multirow{4}{*}{ p-value } \\
\hline & & & & & & & & & \multirow{2}{*}{\multicolumn{2}{|c|}{$\begin{array}{c}\text { Not } \\
\text { according } \\
\text { standard }\end{array}$}} & \multirow{2}{*}{\multicolumn{2}{|c|}{$\begin{array}{c}\text { According } \\
\text { to the } \\
\text { standard }\end{array}$}} & & & & \\
\hline & $\mathbf{f}$ & $\%$ & f & $\%$ & $\mathbf{f}$ & $\%$ & & & & & & & & & & \\
\hline Working & 1 & 14,3 & 6 & 85,7 & 7 & 100 & 0,269 & & $\mathbf{F}$ & $\%$ & f & $\%$ & $\mathbf{F}$ & $\%$ & & \\
\hline Not & 13 & 38,2 & 21 & 61,8 & 34 & 100 & $(0,029$ & Negative & 12 & 46,2 & 14 & 53,8 & 25 & 100 & 12,000 & \\
\hline working & & & & & & & - & Positive & 1 & 6,7 & 14 & 93,3 & 16 & 100 & $(1,370-$ & 0,014 \\
\hline Total & 14 & 34,1 & 27 & 65,9 & 41 & 100 & $2,497)$ & All & 13 & 31,7 & 28 & 68,3 & 41 & 100 & $105,135)$ & \\
\hline
\end{tabular}

Based on the table 5 above shows that the percentage of pregnant women antenatal care visits that don't based on standard is more for unemployee mothers (38.2\%) compared to employee mothers $(14.3 \%)$. Based on statistical tests $p$ value $=0.389(\mathrm{p}>0.05)$, it means there is no association between the job of pregnant women with antenatal care visits at District of Sungayang Health Center, Tanah Datar Regency in 2017.
Table 6. The Association of Knowledge of Pregnant Women with Antenatal Care Visits at District of Sungayang Health Center, Tanah Datar Regency in $\mathbf{2 0 1 7}$

\begin{tabular}{ccccccccc}
\hline \multirow{2}{*}{$\begin{array}{c}\text { Knowled } \\
\text { ge }\end{array}$} & $\begin{array}{c}\text { Antenatal Care Visits } \\
\text { Not } \\
\text { according } \\
\text { standard }\end{array}$ & $\begin{array}{c}\text { According } \\
\text { to the } \\
\text { standard }\end{array}$ & & Total & $\begin{array}{c}\boldsymbol{p} \text { - } \\
\text { value }\end{array}$ \\
\cline { 2 - 6 } & $\mathbf{f}$ & $\mathbf{\%}$ & $\mathbf{f}$ & $\mathbf{\%}$ & $\mathbf{f}$ & $\%$ & \\
\hline Less & 13 & 39,4 & 20 & 60,6 & 33 & 100 & \\
Good & 0 & 0 & 8 & 100 & 8 & 100 & 0,040 \\
Total & $\mathbf{1 3}$ & $\mathbf{3 4 , 9}$ & $\mathbf{2 8}$ & $\mathbf{6 8 , 3}$ & $\mathbf{4 1}$ & $\mathbf{1 0 0}$ & \\
\hline
\end{tabular}

Based on table 6 above shows that the percentage of pregnant women with antenatal care visits based on standard more on pregnant women with good knowledge (100\%) compared to pregnant women with less good knowledge $(60.6 \%)$. These results could not be tested, but there is a tendency of all pregnant women with good knowledge do antenatal care visits at District of Sungayang Health Center, Tanah Datar Regency in 2017.

Table 7. The Association of Attitude of Pregnant Women with Antenatal Care Visits at District of Sungayang Health Center, Tanah Datar Regency in 2017

Based on table 7 above shows pregnant women with antenatal care visits that standard more on mother with a positive attitude (93.3\%) versus mother with mothers with negative attitude $(53.8 \%)$. Based on statistical tests obtained $\mathrm{p}$ value $=0.014(\mathrm{p}<0.05)$, it means there is a significant association between attitude of pregnant women with antenatal care visits at District of Sungayang Health Center, Tanah Datar Regency in 2017. 
Table 8. The Association of Support of the Husband of Pregnant Women with Antenatal Care Visits at District of Sungayang Health Center, Tanah Datar Regency in 2017

\begin{tabular}{|c|c|c|c|c|c|c|c|c|}
\hline \multirow{3}{*}{$\begin{array}{c}\text { Support of } \\
\text { the } \\
\text { Husband }\end{array}$} & \multicolumn{4}{|c|}{ Antenatal Care Visits } & & & \multirow{3}{*}{$\begin{array}{c}\text { POR } \\
(95 \% \\
\text { CI })\end{array}$} & \multirow{3}{*}{$\begin{array}{c}p- \\
\text { value }\end{array}$} \\
\hline & \multicolumn{2}{|c|}{$\begin{array}{c}\text { Not } \\
\text { according } \\
\text { standard }\end{array}$} & \multicolumn{2}{|c|}{$\begin{array}{l}\text { According } \\
\text { to the } \\
\text { standard }\end{array}$} & \multicolumn{2}{|c|}{ Total } & & \\
\hline & $\mathbf{f}$ & $\%$ & $\mathbf{F}$ & $\%$ & $\mathbf{f}$ & $\%$ & & \\
\hline $\begin{array}{c}\text { Don't } \\
\text { support }\end{array}$ & 10 & 50,0 & 10 & 50,0 & 20 & 100 & 6,000 & \\
\hline Support & 3 & 14,3 & 18 & 85,7 & 21 & 100 & $\begin{array}{l}(1,333- \\
26999)\end{array}$ & ,034 \\
\hline Total & 13 & 31,7 & 28 & 68,3 & 41 & 100 & & \\
\hline
\end{tabular}

Based on table 8 above, it shows pregnant women with antenatal care visits based on standard is more on mom with a supportive husband $(85.7 \%)$ compared to mother with a husband that doesn't support her $(50.0 \%)$. Based on statistical tests $p$ value $=0.034(p<0.05)$, it means there is a sigfnifikan association between husband's support with antenatal care visit at District of Sungayang Health Center, Tanah Datar Regency in 2017.

\section{DISCUSSION}

The results of this study show that most pregnant women $(68.3 \%)$ in work area of public health Sungayang in 2017 did antenatal care visit based on standards. Visits of antenatal care is one form of behavior in the utilization of health services. Antenatal care visits should be done at least 4 times during pregnancy. Contact four times with the details once in the first trimester (before 14 weeks gestation) and second trimester (during 14-28 weeks gestational age), then at least 2 times the contacts on the third trimester of pregnancy during 28-36 week and after 36 weeks gestational age. (Kemenkes, 2014).

On table 3 views that pregnant women with antenatal care based on standard is more on unrisky age (68.4\%), compared to a risky age (66.7\%). Most respondents included reproductive age 20-35 year in which the maturity of reproductive organs and mentally to have pregnancy and childbirth is ready. At the age of 20-35 years of pregnant women will tend to do antenatal care visit on a regular basis because ithey feel its very important. While in pregnant women aged $<20$ years tend not fully understand the importance of antenatal care visits on a regular basis while age > 35 years are more likely to be indifferent to antenatal care visits as they may have been feeling experienced pregnancy before.

This study showed expectant mothers with high education level ( $\geq$ High School) more $65.9 \%$, compared to pregnant women with low level of education (<High School) as much as $34.1 \%$. Education is one of the indirect causes of affecting antenatal visit.

The study results by expectant mothers who do not work is $82.9 \%$, while pregnant women who work $17.1 \%$. According to Anderson in Priyoto (2014), mother's employment is one of the factors that affect the utilization of health services (antenatal). Mother's employment status more or less affect the mother's time to utilize the services of health (antenatal care visits).

In this study the majority of expectant mothers have less knowledge about antenatal care visits that is $80.5 \%$, while pregnant women with good knowledge of only $19.5 \%$. This lack of knowledge can be caused by a lack of guidance or health information to pregnant women in the region of clinics Sungayang. In addition, a lack of curiosity about the examination for pregnant woman is considered to be normal may also be one of the cause.

The study found that most $(61.0 \%)$ of pregnant women have a negative attitude in antenatal care visit, while pregnant women who have a positive attitude that is $39.0 \%$. Attitude is a reaction or response that is still closed to a stimulus from a person or object. Attitude consists of belief (faith), ideas, and concepts to form attitudes intact, and knowledge of thinking, beliefs, and emotions that are a reaction or response is still closed from someone's response to a stimulus or object, life, emotional or emotional evaluation against an object, and the trend to act, but not yet constitute an action.

The results of this study show the husband of pregnant women that support in antenatal care visit is $51.2 \%$ and $48.8 \%$ did not support. The support of family or husband is one element of the amplifier for the occurrence of someone's behavior. Support by the husband is needed for the pregnant mother. Support is provided by the husband by paying attention to the health condition of the mother and baby as well as examination of the pregnancy, delivery costs for pregnancy in the health service, as well 
as taking the mother and accompany her for pregnancy examination.

\section{The Association of Age of Pregnant Women with Antenatal Care Visits}

Based on statistical tests p-value $=1.000$ (p $0.05>$ ) which means there is no association between age of pregnant women with visiting antenatal care. In line with the concept of according to Rohmah (2010) stating that the readiness of pregnant women in antenatal services follow relates to changes that occur due to increasing age and interaction with a background experience. In this case there is a conformity between the theory with the results of this study, that group of pregnant women aged 20-35 years doing standard antenatal visits more than $<20$ or $>35$ years group .

Based on the percentage of the results of this research, the mother's age factor likely not much influence on the behaviour of pregnant women for checked her pregnancy, where both expectant mothers with at-risk age group $(<20$ or 35 years) and pregnant women with age not at risk (20-35) have the same opportunity to perform antenatal care visits in accordance with the standards.

\section{The Association of Education of Pregnant Women with Antenatal Care Visits}

Based on statistical tests $\mathrm{p}$ value $=0.017$ $(\mathrm{p}<0.05)$, which means there is significant association between the education of pregnant women with antenatal care visits. This research is also in line with the research done in Tanzania by Gupta, dkk (2014) stating that education is very high with regards to antenatal visits performed by pregnant women where education will affect the knowledge of pregnant women about the utilization of health care services. The research of Kabir (2012) in Bangladesh also showed a strong link between maternal education and utilization of antenatal layananan where the education level of mothers is a strong determining factor in antenatal care visits by pregnant women.

Based on the results of this research can be seen that the level of education a person particularly pregnant women greatly affects the behavior of pregnant women in antental care visit. Pregnant women with high levels of education have the opportunity to do a time 5.8 antenatal visits standard compared to pregnant women with low levels of education.

\section{The Association of Job of Pregnant Women with Antenatal Care Visits}

Based on statistical tests $\mathrm{p}$ value $=0.077$ ( $p>0.05)$, which means there is no association between the job of pregnant women with antenatal care visits. This is in line with the research Susanto, dkk (2016) which found no relationship between the mother's employment status with an examination of antenatal care. The theory of Anderson in Priyoto (2014) mentioned that the mother's job is one of the factors that affect the utilization of health services (antenatal care). Mothers who don't work have more time to take advantage of health services in order to improve the health of the mother and fetus during pregnancy. However, based on the results of this research are all pregnant women who work do antenatal care visits in accordance with the standards. This illustrates both working mothers and that did not work actually has the same opportunity to perform antenatal care visits in accordance with the standards. Where only $32.8 \%$ of pregnant women don't work that do not appropriate antenatal care visits; Here can be seen both working mothers who do not work or have the same opportunities to perform antenatal care visits appropriate standards or employment status of mothers not related to antenatal care visits.

\section{The Association of Knowledge of Pregnant Women with Antenatal Care Visits}

Based on statistical tests, these results could not be tested, but there is a tendency of all pregnant women with knowledge of good antenatal care visit to appropriate standards. Research Patel, dkk (2016) in Maharashtra, India also stated that there is a relationship between knowledge with practice of antenatal care performed by pregnant women. Pregnant women who have a knowledge of good practice have been applying antenatal care visits properly.

Tamaka, et.al (2013) stated that mothers with less good knowledge but do visit the ANC in accordance with standards may be due to factors which cause such so that despite having less knowledge good but regular in visit ANC. contributing factor as the distance of the place of residence, such as the distance of the place of residence of pregnant women who have a place to stay close to the health service and also with 
the support of a husband because pregnant women who come to do the examination was accompanied by her husband will be motivated to do the inspection of pregnancy.

Based on research by Y Yulizawati, A Nurdiyan, D Iryani, AA Insani in Journal of Midwifery 1 (2), 11-20 in 2016 stated that knowledge of women also influenced by media. If women exposured by many media that tell about some information, so th information will delivered and remembered by mother better than less media (Y Yulizawati, A Nurdiyan, D Iryani, AA Insani, 2016).

In this study the majority of the visible knowledge of pregnant women about antenatal care visits is still lacking. Most pregnant women do not know about the visit at least in pregnancy examination, service anything he dapatlan when checked my pregnancy, and less knowledgeable about the purpose of doing good for the mother's pregnancy examination as well as for the fetus. Pregnant women in the study also still less know about the hazard and risk in pregnancy. Therefore, to address the lack of knowledge of pregnant women this required additional information or intervention such as health education to pregnant women is related to antenatal care visits to health care personnel.

\section{The Association of Attitude of Pregnant Women with Antenatal Care Visits}

Based on statistical tests $\mathrm{p}$ value $=0.014$ $(\mathrm{p}<0.05)$ which means there is a significant association between attitude of pregnant women with antenatal care visits. In this study, the majority of pregnant women is still much in doubt answer about pregnancy examination at a minimum number of visits that will he do. This has a relationship with less knowledge about the visits of antenatal care in pregnant women. Knowledge will affect the attitude of a person towards something. Positive and negative attitude is closely associated with the person's behavior. With a good knowledge and a positive attitude will encourage the person's behavior toward better especially in the implementation of antenatal care visits for pregnant women.

In a study conducted by Ibrahim, et.al (2014) in Libya said that knowledge will influence someone to be positive or negative. Someone who has a good knowledge will have an impact on the attitude positive. Pregnant women with a positive attitude has the opportunity to perform 12 times a visit antenatal care standards compared pregnant women with a negative attitude.

The Association of Support of the Husband of Pregnant Women with Antenatal Care Visits

Based on statistical tests $\mathrm{p}$ value $=0.034$ $(\mathrm{p}<0.05)$ which means there is a sifnifikan association between the husband's support of pregnant women visiting antenatal care. Research by Pafs, dkk (2015) in Rwanda stated that women who are not supported by her partner in pregnancy, potentially putting them at risk of morbidity is higher. Therefore, family support especially husband desperately needed by the mother during her pregnancy, either physical or psychological support. In the study, Pruthi et.al (2016) in India stated that $82 \%$ of men felt their primary role is to provide financial support to families rather than engage in preparation for childbirth pregnancy examination of his wife in particular. In the study stated that exposure to maternal health education and knowledge of maternal health is the major Predictor of engagement husband. In addition, women are more likely to use health services while their husbands to accompany the ANC visit.

Support the husband becomes the deciding factor because it will give the spouse support strengthening against the motivation to perform antenatal care visits. Husbands who have knowledge or understanding is more able to provide explanations and its support on the wife to carry out healthy behavior in this case included an examination of pregnancy. The results of this study in accordance with the theory, in which pregnant women are antenatal care visit standard $85.7 \%$ support the husband. In this case, pregnant women with husbands who support having the opportunity to make a visit time 6 antenatal care standards compared to pregnant women with husbands that don't support.

\section{The Limitations Of The Research}

There are several limitations of this study, which are: the variables examined, only limited to age, education, employment, knowledge, attitude, and support her husband, due to some considerations and the limitations. data collection by using questionnaire was subjective, so the information we got depends on the honesty of pregnant women at the time of answering questions and statements filed. 


\section{CONCLUSSION}

1. There is no association between age and job with antenatal care visits.

2. There is a association between education, the attitude of the mother, the support of a husband with antenatal care visits.

3. There is a trend of the relationship between knowledge with antenatal care visits.

\section{REFERENCES}

Badan Pusat Statistik (BPS). Kabupaten Tanah Datar dalam Angka. BPS Kabupaten Tanah Datar. Tanah Datar. 2016.

Gupta, S, dkk. Factors Associated with Four or More Antenatal Care Visits and Its Decline among Pregnant Women in Tanzania between 1999 and 2010. Plos One 9 (7). 2014. P 1-13.

Ibrahim, H.K., Borgy, El. M.D., dan Mohammed H.O. Knowledge, Attitude, and Practices of Pregnant Women towards Antenatal Care in Primary Healthcare Centers in Benghazi, Libya. Journal of thr Egyptian Public Health Association 89 (3). 2014. P 119-126

Kabir, M. R. Does Mother's education affect antenatal care visits in Bangladesh?. Sweden. Thesis. Umea University, 2012.

Kementerian Kesehatan RI. Buku Ajar Kesehatan Ibu dan Anak. Jakarta. Pusat Pendidikan dan Pelatihan Tenaga Kesehatan. 2014.

Kementerian Kesehatan RI. Profil Kesehatan Indonesia Tahun 2014. Jakarta. Kemenkes RI. 2015.

Kementerian Kesehatan RI. Profil Kesehatan Indonesia Tahun 2015. Jakarta. Kemenkes RI. 2016.

Notoatmodjo, S. Promosi Kesehatan Teori dan Aplikasi. Jakarta. Rineka Cipta. 2005.

Pafs, J., Musafili, A., Finnema, P.B., Allvin, M. K., Rulisa, S., dan Essen, B. 'They would never receive you without a husband': Paradoxical barriers to antenatal care scale-up in Rwanda. Elsevier Midwifery 31. 2015.P 1149-1156.

Patel, B.B., Gurmeet, P., Sinalkar, D.R., Pandya, K.H., Mahen, A, dan Singh. N. A Study on Knowledge and Practices of Antenatal Care Among Pregnant Women Attending Antenatal Clinic at a Tertiary Care Hospital of Pune, Maharashtra. Medical Journal of Dr. D.Y. Patil University 10 (3). 2016. P 354-362.

Priyoto. Teori Sikap dan Perilaku dalam Kesehatan. Yogyakarta. Nuha Medika. 2014.

Pruthi, N., Bacchani, S., dan Singh, V. Knowledge, attitude and practice regarding antenatal care among husbands attending antenatal clinic in a tertiary care hospital. Intenational Journal of Community Medicine and Public Health 3(7). 2016. P 1741-1744.

Rohmah, N. Pendidikan Prenatal Upaya Promosi Kesehatan Bagi Ibu Hamil. Depok. Gramata Publishing. 2010.

Siwi, E. W. Materi Ajar Lengkap Kebidanan Komunitas. Yogyakarta. PUSTAKABARUPRESS. 2014. 
Susanto, J., Ahmad, L.O.A.I., dan Suriani, C. Faktor yang Berhubungan dengan Pemeriksaan Antenatal Care (ANC) Kunjungan 1- Kunjungan 4 (K1-K4) pada Ibu Hamil di RSUD Kota Kendari tahun 2016. http://ojs.uho.ac.id/index.php/JIMKESMAS/article/view/1252. 25 Juli 2017 (06:51).

Tamaka, C., Madianung, A., dan Sambeka, J. Hubungan Pengetahuan Ibu Hamil dengan Keteraturan Pemeriksaan Antenatal Care di Puskesmas Bahu Kecamatan Malalayang Kota Manado. Ejurnal Keperawatan 1 (1). 2013. P 1-6

World Health Organization (WHO). Health Statistics and Information Systems. http://www.who.int/healthinfo/statistics/indmaternalmortality/en/. 2 November 2016 (19:00). 2016.

World Health Organization (WHO). Media Center (Maternal Mortality). http://www.who.int/mediacentre/factsheets/fs348/en/. 2 November 2016 (19:10). 2016.

World Health Organization (WHO). Global Health Observatory (GHO) Data. http://www.who.int/gho/maternal_health/mortality/maternal/en/index2.html. 2 November $2016(19: 13) 2016$.

Y Yulizawati, A Nurdiyan, D Iryani, AA Insani. Pengaruh Pendidikan Kesehatan Metode Peer Education Mengenai Skrining Prakonsepsi Terhadap Pengetahuan Dan Sikap Wanita Usia Subur Di Wilayah Kabupaten Agam Tahun 2016. Journal of Midwifery 1 (2). 2016. P 11-20 